\title{
Micromycetes antagonistic potential in vitro against Alternaria sp., a pathogenic strain associated with grapes
}

\author{
Margarita Burovinskaya $^{1^{*}}$, Lyubov Maslienko ${ }^{2}$ and Evgeniya Yurchenko $^{1}$ \\ ${ }^{1}$ Federal State Budgetary Scientific Institution «North Caucasian Federal Scientific Center of \\ Horticulture, Viticulture, Wine-making», str. 40 Let Pobedy, 39, Krasnodar, 350901, Russia \\ ${ }^{2}$ Federal State Budgetary Scientific Institution «Federal scientific center «V.S. Pustovoit All-Russian \\ Research Institute of Oil crops», str. Filatova, 17, Krasnodar, 350038, Russia
}

\begin{abstract}
Fungi from the genus Alternaria Nees are new harmful grapes mycopathogens; they are a part of the necrotic leaf spot pathocomplex. The disease intensive development leads to more than $50 \%$ necrotisation of the leaf surface, leaving no leaf on the plant by the end of the growing season. An alternative to chemical protection against the disease is the use of biocontrol agents. For this purpose, the screening of fungal antagonist strains from the collection of the laboratory of the biological method of the Federal scientific center «V.S. Pustovoit All-Russian Research Institute of Oil crops» (FSBSI «FSC «ARRIOC») was carried out in relation to the causative agent of necrotic leaf spot of grapes Alternaria sp. by the dual cultures method on two nutrient media - potato-sucrose agar and Rudakov's agar. Of the 27 fungal strains that were screened for the antagonistic activity to 425-3 Alternaria sp. 17 strains showed the activity. Of these, 12 strains competed for feeding area and exhibited hyperparasitism. Strains A-1 and I3 Basidiomycota, Tr-1 Trichothecium sp. and all strains of Trichoderma sp. showed the greatest antagonistic activity on both media.
\end{abstract}

\section{Introduction}

The specialists' interest of all over the world does not fade away in studies of the leaf spots etiology in agricultural crops caused by pathogenic species of the genus Alternaria Nees on cereals, oilseeds, many vegetable and fruit plantations [1]. For grapes, these fungi are new mycopathogens that are part of the necrotic leaf spot pathocomplex [2, 3]. In the Western Ciscaucasia vineyards, in recent years, the disease has been observed mainly in interspecific hybrids. Necrotic leaf spot is regarded to be harmful. Due to a decrease in the photosynthetic activity of grape plants, the yield from a bush can decrease by $18-27 \%$ and sugar in berries lowers by $6.1-9.1 \%$, as well. Chemical fungicides used to protect grapes from mycopathogens not only worsen the ecological situation of perennial agrocenoses, but can also be phytotoxic. In addition, there are reports of the appearance in populations of pathogenic fungi Alternaria

\footnotetext{
*Corresponding author: rita-miss@mail.ru
} 
resistant to chemical fungicides $[4,5]$. While implementing an ecological approach to reducing morbidity, the best alternative is the use of biological control agents.

Currently, the search for effective fungal antagonist strains is aptly relevant [6-8]. Studies of biological activity have shown that strains of various Trichoderma species inhibit the growth of Alternaria fungal pathogens [9]. For example, in an experiment presented by Indian scientists in 2015 [10], in dual cultures with the onion pathogen Alternaria porri, a strong suppression of the mycelium pathogen growth by strains of Trichoderma viride Pers. (76.55\%) and Trichoderma harzianum Rifai (70.74\%) [10]. Another study established a high percentage of growth inhibition of the tomato pathogen Alternaria solani Sorauer by the T. viride strain (77\%) [11]. Kayim et.al. (2018) showed that the T. harzianum antagonist inhibited the growth of the leaf spot pathogen A. alternata by $53.85-82.81 \%$ [12]. Trichoderma asperellum strains exhibited high hyperparasitic activity against Alternaria fungi [13].

\section{Materials and methods}

The objects of research were grape leaves with symptoms of necrotic leaf spot, Alternaria sp. isolates, and fungal strains collection of the FSBSI «FSC «ARRIOC» biological method laboratory. The place of research is the laboratory of the biomedical method of the FSBSI «SC «ARRIOC».

Alternaria sp. mycopathogen was isolated from the necrotic leaf spot pathocomplex of grapes - Alternaria sp. (isolate 425-3). To isolate the fungi, we used standard microbiological techniques - incubating in moisture chambers in Petri dish and in agarized nutrient media [14].

To determine the antagonistic activity of fungal strains, the method of dual cultures was used [15]. The growth of the pathogen and antagonist as a percentage of the Petri dish area (competition for the feeding area) and the nature of their interaction were noted: the presence of a growth retardation zone of the test object as a result of antibiotic substances or hydrolytic enzymes release by the antagonist (sterile zone, $\mathrm{mm}$ ); antagonist growth per pathogen colony (hyperparasitic zone, $\mathrm{cm}^{2}$ ). The experiment was repeated four times.

\section{Results and discussions}

On Rudakov's agar, the isolate of the causative agent of necrotic leaf spot Alternaria sp. occupied $89.3 \%$ of the nutrient medium surface for ten days of cultivation. Of the 27 fungal strains, 17 strains showed antagonistic activity to the causative agent of necrotic leaf spot after ten days of cultivation in a dual culture on Rudakov's agar. Of these, 12 strains exhibited an active competition for the feeding area and hyperparasitism.

Being a part of the FSBSI «FSC «ARRIOC» fungal strains collection all strains from the Trichoderma sp. genus, A-1 and I-3 Basidiomycota strains, Tr-1 Trichothecium sp. showed the antagonistic activity against the causative agent of necrotic leaf spot. (Table 1).

Table 1. Antagonistic activity of antagonist fungi strains against the causative agent of Alternaria sp., the necrotic leaf spot of grape, at temperature of $25^{\circ} \mathrm{C}$ on Rudakov's agar, on the 10th day of cultivation

\begin{tabular}{|c|c|c|c|}
\hline \multirow{3}{*}{ Strain of antagonist } & \multicolumn{2}{|c|}{$\begin{array}{c}\text { Area of the nutrient medium } \\
\text { surface colonization }\end{array}$} & \multirow{2}{*}{ Hyperparasitic zone, $\mathrm{cm}^{2}$} \\
\cline { 2 - 3 } & Antagonist & Pathogen & \\
\cline { 2 - 3 } & $\%$ & $\%$ & - \\
\hline Alternaria sp.(control) & - & 89.3 & - \\
\hline \multicolumn{2}{|c|}{ Competition for the feeding area with hyperparasitism } \\
\hline
\end{tabular}




\begin{tabular}{|c|c|c|c|}
\hline \multirow{3}{*}{ Strain of antagonist } & \multicolumn{2}{|c|}{$\begin{array}{l}\text { Area of the nutrient medium } \\
\text { surface colonization }\end{array}$} & \multirow{3}{*}{ Hyperparasitic zone, $\mathrm{cm}^{2}$} \\
\hline & Antagonist & Pathogen & \\
\hline & $\%$ & $\%$ & \\
\hline T-4 Trichoderma sp. & 100 & 19.3 & 15.6 \\
\hline T-5 Trichoderma sp. & 100 & 20.0 & 16.2 \\
\hline T-3 Trichoderma sp. & 100 & 21.7 & 17.6 \\
\hline T-1 Trichoderma sp. & 100 & 21.9 & 17.7 \\
\hline T-2 Trichoderma sp. & 100 & 23.7 & 19.2 \\
\hline Tr-1 Trichothecium sp. & 100 & 44.6 & 36.1 \\
\hline A-1 Basidiomycota sp. & 100 & 46.0 & 37.3 \\
\hline Tk-1 Trichoderma sp. & 85.6 & 50.5 & 32.5 \\
\hline И-3 Basidiomycota sp. & 88.9 & 44.6 & 29.5 \\
\hline An-1 Aspergillus sp. & 70.0 & 37.5 & 7.8 \\
\hline SM-1 Sordaria sp. & 79.7 & 20.4 & 1.4 \\
\hline Ma-1 Metarhizium sp. & 75.2 & 25.9 & 0.9 \\
\hline Pr-1 Penicillium sp. & 26.3 & 54.2 & 3.7 \\
\hline Хк-3 Chaetomium sp. & 51.7 & 54.4 & 3.4 \\
\hline Хк-1 Chaetomium sp. & 47.3 & 55.6 & 3.5 \\
\hline Pf-1 Penicillium sp. & 20.0 & 61.2 & 3.0 \\
\hline Хк-4 Chaetomium sp. & 47.8 & 56.8 & 1.9 \\
\hline
\end{tabular}

A group of six strains belonging to the genus Trichoderma (Tk-1, T-1, T-2, T-3, T-4, T5 Trichoderma sp.) showed the greatest ability to compete for feeding area in relation to the pathogen necrotic leaf spot in combination with complete overgrowth of the pathogen with an antagonist (hyperparasitism) (Fig. 1).

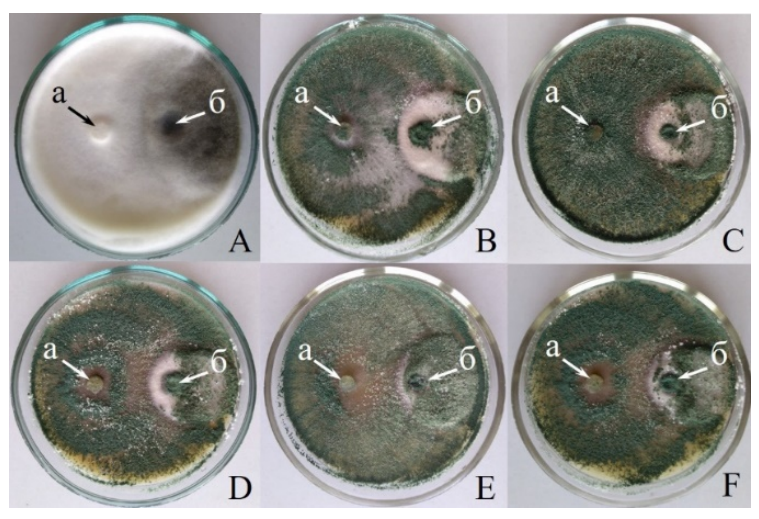

Fig. 1. Antagonistic activity of fungal strains from the genus Trichoderma to the causative agent of necrotic leaf spot on grapes after 10 days of cultivation on Rudakov's agar: A - Tk-1 Trichoderma sp., B - T-1 Trichoderma sp.; C - T-2 Trichoderma sp.; D - T-3 Trichoderma sp.; E - T-4 Trichoderma sp.; F - T-5 Trichoderma sp. a - antagonist; b - pathogen.

On potato sucrose agar (PSA), a causative agent isolate of the necrotic leaf spot Alternaria sp. occupied $100 \%$ surface of the nutrient medium within ten days of cultivation (Table 2). 
Table 2. Antagonistic activity of Alternaria sp. antagonist fungi strains to the causative agent of necrotic leaf spot of grapes, at a temperature of $25^{\circ} \mathrm{C}$ on PSA, on the 10th day of cultivation

\begin{tabular}{|l|c|c|c|c|}
\hline \multirow{2}{*}{ Strain of antagonist } & \multicolumn{2}{|c|}{$\begin{array}{c}\text { Area of the nutrient medium } \\
\text { surface colonization }\end{array}$} & \multirow{2}{*}{ S, $\mathrm{cm}^{2}$} & \multirow{2}{*}{ K1, mm } \\
\cline { 2 - 3 } & Antagonist & Pathogen & & \\
\cline { 2 - 3 } & $\%$ & $\%$ & & \\
\hline Alternaria sp. (контроль) & - & 100 & - & \\
\hline \multicolumn{2}{|c|}{ Competition for the feeding area with hyperparasitism and antibiosis } \\
\hline A-1 Basidiomycota & 100.0 & 52.7 & 42.7 & 0 \\
\hline T-2 Trichoderma sp. & 100.0 & 38.1 & 30.9 & 7.0 \\
\hline T-4 Trichoderma sp. & 96.2 & 29.4 & 15.6 & 26.2 \\
\hline Tr-1 Trichothecium sp. & 91.7 & 42.8 & 25.7 & 0 \\
\hline Tk-1 Trichoderma sp. & 88.0 & 45.4 & 25.1 & 0 \\
\hline T-1 Trichoderma sp. & 87.3 & 47.3 & 27.0 & 4.5 \\
\hline T-3 Trichoderma sp. & 77.8 & 41.7 & 18.1 & 13.0 \\
\hline T-5 Trichoderma sp. & 79.5 & 40.2 & 16.8 & 8.0 \\
\hline SM-1 Sordaria sp. & 80.5 & 19.5 & 0.6 & 0 \\
\hline \multicolumn{4}{|c|}{ Antagonist suppression by pathogen } \\
\hline Pk-1 Penicillium sp. & 41.5 & 62.2 & 4.0 & 0 \\
\hline Pv-3 Penicillium sp. & 37.9 & 55.1 & 3.5 & 0 \\
\hline Xк-3 Chaetomium sp. & 44.1 & 57.3 & 2.4 & 0 \\
\hline
\end{tabular}

Note: $\mathrm{S}$ is the area of the hyperparasitic zone; K1 - the size of the sterile zone

The antagonistic activity of antagonist strains on PSA medium was found to be somewhat different from the one on Rudakov's agar. The overgrowth area of the nutrient medium with antagonists was much smaller, while the pathogen managed to occupy $19.5-69.5 \%$. The maximum competition for feeding area (100\%) and hyperparasitism were observed in A1 Basidiomycota (42.7\%) and T-2 Trichoderma sp. (30.9\%).

Other strains of the genus Trichoderma (T-1, Tk-1, T-3, T-5 Trichoderma sp.) also showed a high competitive activity (77.8-96.2\%), and hyperparasitism $(15.6-27.0 \mathrm{~cm} 2)$. In addition, four strains of this genus had a pronounced antibiosis; the maximum sterile zone was found in strains T-3 and T-4 Trichoderma sp. (fig. 2 C, D, E, F).

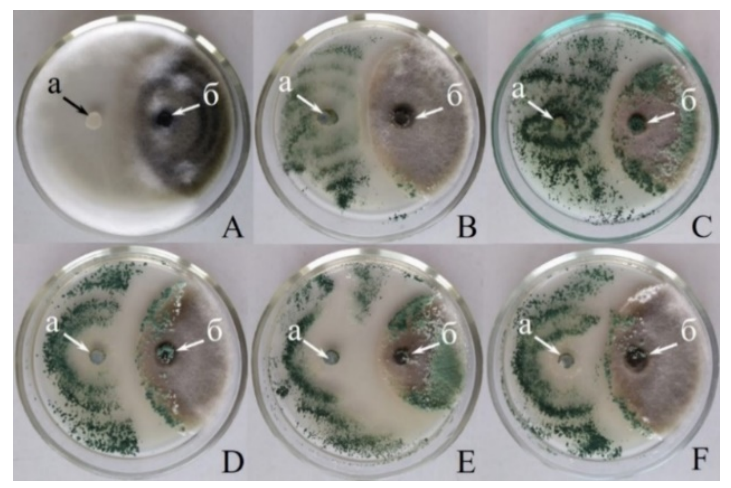

Fig. 2. Antagonistic activity of fungal strains from the genus Trichoderma to the causative agent of necrotic leaf spot on grapes after 10 days cultivation on potato-sucrose agar: A - Tk-1 Trichoderma sp .; B - T-1 Trichoderma sp.; C - T-2 Trichoderma sp.; D - T-3 Trichoderma sp.; E - T-4

Trichoderma sp.; F - T-5 Trichoderma sp. a - antagonist;

$\mathrm{b}$ - pathogen. 


\section{Conclusion}

A-1 and I-3 Basidiomycota strains, Tr-1 Trichothecium sp. and all strains of Trichoderma sp. can be considered as promising antagonists for further field trials. T-1, Tk-1, T-3, T-5 Trichoderma sp. strains can be used as producers of antibiotic substances against the fungi Alternaria $s p$., because when cultivated in a dual culture, they caused the pathogen growth retardation zone (sterile zone).

Acknowledgments. The reported study was funded by KSF according to the research project № MFI20.1-9/20.

\section{References}

1. A. Patriarca, G. Vaamonde, V.F. Pinto, Encylopedia of Food Microbiology, 54-60 (2014) https://doi.org/10.1016/B978-0-08-100596-5.22572-9

2. M. Burovinskaya, L. Maslienko, E. Yurchenko, E3S Web Conferences, 254, 05004 (2021) https://doi.org/10.1051/e3sconf/202125405004

3. E.G. Yurchenko, M.V. Burovinskaya, Pomiculture and small fruits culture in Russia, 58, 194-200 (2019) https://doi.org/10.31676/2073-4948-2019-58-194-200

4. M.G. Kgatle, B. Flett, M. Truter, T.A.S. Aveling, Crop Prot., 132, 105146 (2020) https://doi.org/10.1016/j.cropro.2020.105146

5. S. Yuan, W. Li, Q. Li, L. Wang, J. Cao, W. Jiang, J. Agric. Food Chem., 67, 2801-2810 (2019) https://doi.org/10.1021/acs.jafc.9b00087

6. J. Köhl, R. Kolnaar, W.J. Ravensberg, Front. Plant Sci., 10, 845 (2019) https://doi.org/10.3389/fpls.2019.00845.

7. I. Ahmad, F. Ahmad, J. Pichtel, Microbes and Microbial Technology: Agricultural and Environmental Applications (Springer, 2011) https://dx.doi.org/10.1007/978-1-44197931-5

8. M. Adnan, W. Islam, A. Shabbir, K.A. Khan, H.A. Ghramh, Z. Huang, H.Y.H. Chen, G.d. Lu, Microb, Pathog,, 129, 7-18 (2019) https://doi.org/10.1016/j.micpath.2019.01.042

9. G.E. Harman, N. Uphoff, Scientifica, 2019, $25 \quad$ (2019) https://doi.org/10.1155/2019/9106395

10. A. Tapwal, G. Thakur, S. Chandra, A Tyagi, International Journal of Biological and Chemical Sciences, 1(10), 14-19 (2015) (PDF) In-vitro evaluation of Trichoderma species against seed borne pathogens (researchgate.net)

11. O.Y. Kapgate, U.K. Khare, N.M. Kelwatkar, J. Pharm. and Phytochem., 8 (4), 3164-3168 (2019) https://www.phytojournal.com/archives/2019/vol8issue4/PartAZ/8-4-634788.pdf

12. M. Kayim, A.M. Yones, A. Endes, Harran Tarim ve Gida Bilimleri Dergisi, 22 (2), 169178 (2018) https://doi.org/10.29050/harranziraat.329976

13. Z. Yu, Z. Liu, Y. Zhang, Z. Wang, J. Forest. Res. (2021) https://doi.org/10.1007/s11676021-01332-W

14. A. Garibaldi, G. Gilardi, S. Matic, I. Luongo, M.L. Gullino, Plant Disease, 104(9), 2515 (2020) https://doi.org/10.1094/PDIS-02-20-0346-PDN

15. L.V. Maslienko, A.Kh. Voronkova, L.A. Datsenko, E.A. Efimtseva, D.A. Punogina, S.A. Gaydukova, V.V. Kazakova, S.R. Kovaleva, Oilseed crops, 2, 103-111 (2020) https://doi.org/10.25230/2412-608X-2020-2-182 